Original article

\title{
Enhancing prediction accuracy of soil respiration in an apple orchard by integrating photosynthetic activity into a temperature-related model
}

\author{
F. Scandellari a, *, D. Zanotelli a , C. Ceccon ${ }^{\text {a }}$, M. Bolognesi ${ }^{\text {a }}$, L. Montagnani ${ }^{\text {a }}$, P. Cassol ${ }^{\text {b }}$, \\ G.W. Melo ${ }^{\mathrm{c}}$, M. Tagliavini ${ }^{\mathrm{a}}$ \\ ${ }^{a}$ Free University of Bolzano-Bozen, Faculty of Science and Technology, Piazza Università, 1, I-39100 Bolzano-Bozen, Italy \\ ${ }^{\mathrm{b}}$ Universidade do estado de Santa Catarina, Centro de Ciências Agroveterinárias, Av. Luiz de Camões, 2090, 88520-000 Lages, SC, Brazil \\ ${ }^{c}$ Empresa Brasileira de Pesquisa Agropecuária, Centro Nacional de Pesquisa de Uva e Vinho, Rua Livramento, 515, 95700-000 Bento Gonçalves, RS, Brazil
}

\section{A R T I C L E I N F O}

\section{Article history:}

Received 18 May 2015

Received in revised form 21 July 2015

Accepted 22 July 2015

Available online $\mathrm{xxx}$

\section{Keywords:}

Carbon

Gross primary productivity

Light

Net primary productivity

Roots

\begin{abstract}
A B S T R A C T
Temperature is often used as the primary driver to model soil respiration ( $\mathrm{R}_{\mathrm{S}}$ ) and several models based only on temperature have been used to estimate it, with a variable degree of accuracy. An adequate availability of photosynthates translocated from the canopy also affects root respiration $\left(R_{R}\right)$ and therefore $R_{S}$. In this work, carried out in an apple orchard for three years, we assessed the role of temperature to $R_{S}$ and its autotrophic $\left(R_{R}\right)$ and heterotrophic $\left(R_{H}\right)$ components. We also determined the variation over the season of $\mathrm{R}_{\mathrm{S}}$ at a reference temperature and related it to concurrent data of gross primary productivity at ecosystem level (GPP), light (PPFD), air temperature (Tair), orchard net primary productivity (NPP) and root growth rate. Several of these factors were then incorporated into a model to estimate Rs. Data showed that temperature alone explained less than $50 \%$ of Rs variability at yearly scale. GPP, NPP, PPFD and Tair were correlated to $R_{S}$ at a reference temperature. The contribution of root respiration to $R_{S}$ increased with increasing photosynthetic activity, total tree and root growth, PPFD and Tair. On a diurnal scale, the time lag between the pattern of GPP and the pattern of $R_{R}$ was between 2.5 and $3 \mathrm{~h}$ during the growing season, decreasing to 1.5 after fruit harvest. Including GPP, NPP, PPFD and Tair to a temperature-based model improved its predicting power of $R_{S}$. The results confirm the existence of a tight coupling between plant metabolism and root-derived soil respiration in the apple orchard.
\end{abstract}

() 2015 Elsevier Masson SAS. All rights reserved.

\section{Introduction}

The emission of carbon dioxide $\left(\mathrm{CO}_{2}\right)$ from soil is the major ecosystem carbon flux after photosynthesis [1]. This flux can origin from plant roots and their associated organisms (root respiration, $R_{R}$ ) or can be produced by soil microorganisms decomposing the soil organic matter (heterotrophic respiration, $\mathrm{R}_{\mathrm{H}}$ ). It has been highlighted that the sharp separation of these two components is actually an artifact because of the important role of rhizospheric microorganisms to soil respiration (i.e. heterotrophic respiration, but associated with roots). However, this conceptual splitting is useful in ecological research to study the factors controlling these processes [2-4].

\footnotetext{
* Corresponding author.

E-mail address: francesca.scandellari@unibz.it (F. Scandellari).
}

Temperature is used as the primary driver to model soil respiration. Many equations have been developed over the years to relate these two variables [5], the two most common likely being the exponential function known as $\mathrm{Q}_{10}$ and the Arrhenius-derived Lloyd and Taylor [6]. Both models estimate two parameters representing the respiration flux at a fixed temperature (known as basal respiration, BR, in the exponential model, and as Rref, in the Arrhenius-derived model) and the sensitivity of respiration to temperature changes (known as $\mathrm{Q}_{10}$ and $\mathrm{E}_{0}$, respectively). Both models, although very effective under the climatic conditions observed in many ecosystems, suffer of the drawback of predicting an indefinite increase of $\mathrm{CO}_{2}$ flux with increasing temperature [5], an effect which is highly unlikely due to the existence of temperature optima for all organisms, exceeded which the inhibition of vital functions, including respiration, can be observed $[7,8]$. In addition, both models display the downside of relating the respiration flux to temperature only, a convenient, but insufficient 
representation of respiration drivers in ecosystems [9-11]. One of the main issues is that soil respiration at reference temperature conditions, i.e. BR or Rref, clearly changes over the season $[12,13]$ indicating the existence of a temperature-independent -represented by BR or by Rref- and a temperature-dependent portion of soil respiration, that should be taken into account when modelling these processes [12].

Soil respiration at a reference temperature may be used to compare $\mathrm{R}_{S}$ of different ecosystems [14-16]. However much of the observed variation in soil respiration is probably attributable to variation in substrate availability in space and time $[10,17,18]$ thus it is necessary to include variables accounting for this factor into soil respiration modelling [19]. Autotrophic respiration, which may represent the majority of respired $\mathrm{CO}_{2}$ during periods of high productivity [20], is linked to aboveground $\mathrm{C}$ assimilation and $\mathrm{C}$ transport to roots via plants' phloem, and therefore it is not exclusively controlled by temperature [21]. Continuous measurements of gross primary productivity (GPP), such as those deriving from the eddy covariance technique, as well as periodic measurements of net primary productivity (NPP), allow knowing the current organic C production of the ecosystems, which can be used as a proxy of C supply to roots [19]. Environmental drivers such as the available photosynthetic radiation (PPFD) and the mean daily air temperature (Tair) are well correlated to the $C$ assimilation capacity of an ecosystem and could also be used as a proxy for C availability to the plants. An adequate availability of photosynthates translocated from the canopy affects root respiration and therefore $\mathrm{R}_{\mathrm{S}}$. Roots need $\mathrm{C}$ for their maintenance respiration and, especially during growth periods, for growth respiration [22]. Root density and root growth therefore affect $R_{R}$.

Many studies dealt with soil respiration in forests and grasslands, but far less in agricultural ecosystems, especially in orchards [23-27]. With this research, we intended to relate the seasonal variation of $\mathrm{CO}_{2}$ emissions from soil due to heterotrophic and to root activities with environmental and biological parameters in an apple orchard located in Northern Italy. We applied the trenching technique to partition between the two soil respiration components [28]. The respiration at a reference temperature was used to assess the influence of assimilate supply, by correlating it with four parameters assessed independently and serving as proxy for $\mathrm{C}$ supply to roots (temperature, photosynthetically active radiation, net and gross primary productivity). The objectives of this work were:

i) to assess the effect of temperature on $R_{S}$ and its autotrofic $\left(R_{R}\right)$ and heterotrophic $\left(R_{H}\right)$ components;

ii) to relate the assimilatory and the respiratory $\mathrm{CO}_{2}$ fluxes at a diurnal time scale;

iii) to relate the respiration at a reference temperature with concurrent data of gross primary productivity at the ecosystem level (GPP), light (PPFD), air temperature (Tair), orchard net primary productivity (NPP) and root growth rate;

iv) to incorporate into a model to estimate $R_{S}$ the photosynthetic activity (GPP) or other main variables (PPFD, Tair and NPP) that covary with photosynthesis during the season.

\section{Material and methods}

\subsection{Site description}

The experimental site is an organically-managed apple orchard established in 2000 and located in Northern Italy, in the province of Bolzano (46 $\mathrm{N}, 21^{\prime} ; 11^{\circ} \mathrm{E} 16^{\prime} ; 240 \mathrm{~m}$ a.s.l.). Apple trees (Malus domestica var. Fuji grafted on M9 rootstock) are spaced $3 \times 1 \mathrm{~m}$, trained as slender-spindle, and irrigated with the sprinkler overhead method. Trees were fertilized twice a year with organic fertilizers. The soil strip underneath the trees (1.2 m large) was kept free from weeds by periodic mechanical tillage of the top soil layer. Tree rows were Est-West oriented. Mean precipitation of the area in the previous 20 years averaged $838 \mathrm{~mm} \mathrm{y}^{-1}$; the annual mean temperature was $12.5^{\circ} \mathrm{C}$. In the upper $60 \mathrm{~cm}$ layer, the soil (Calcaric Cambisols according to FAO Soil Taxonomy) had the following characteristics: $\mathrm{pH}=7.4$, organic carbon $=1.43 \%$ and total nitrogen $=0.17 \%$; soil texture was $44 \%$ sand, $45 \%$ lime and $11 \%$ clay.

An eddy covariance tower has been measuring $C$ fluxes at the ecosystem level since March 2009 [29]. Six plots with a surface of $12 \mathrm{~m}^{2}$ containing five trees each were chosen for soil $\mathrm{CO}_{2}$ flux and ancillary measurements (Fig. 1).

\subsection{Soil $\mathrm{CO}_{2}$ flux}

Soil respiration was measured by an automated soil $\mathrm{CO}_{2}$ flux system coupled with a multiplexer allowing the continuous, unattended measurement of 8 positions using long-term dark chambers (LI-8100 + LI-8150 with 8 chambers type LI-8100-104; Li-Cor Biosciences, Lincoln, Nebraska, USA). Four chambers were kept on the same position for the whole season, while the other four were rotated over 12 different positions on a weekly basis. Plastic collars for soil respiration measurements were placed on site in January 2010. The collars had an inner diameter of $20 \mathrm{~cm}$ and a height of $11 \mathrm{~cm}$; they were permanently inserted in the soil, equally distributed in the north and south side of the apple trees, at a depth of $3 \mathrm{~cm}$ and placed to have the centre at a distance of $30 \mathrm{~cm}$ from the tree row, between two adjacent trees (Fig. 1). Half of the collars were placed on undisturbed soil areas to measure total soil respiration, and half were placed on areas where in June 2009 a trench of $50 \times 50 \mathrm{~cm}$ was excavated to a depth of $60 \mathrm{~cm}$. To avoid the growth of tree roots into the trenched area, a lining resistant to decomposition and to root penetration, but permeable to water and air, was inserted into the trench that was then refilled with soil. Although the mesh of the tissue used to trench was likely not small enough to stop the growth of mycorrhizal hyphae, soil respiration measurements taken from the trenched areas were assumed to be equal to heterotrophic respiration $\left(\mathrm{R}_{\mathrm{H}}\right)$. The herbaceous vegetation growing along the tree alley and inside the trenched soil areas was periodically removed by hand.

Soil respiration from each collar was measured every $30 \mathrm{~min}$ and each measurement lasted $2 \mathrm{~min}$ and $35 \mathrm{~s}$ during which $\mathrm{CO}_{2}$ concentration was measured every second; the first $45 \mathrm{~s}$ were considered as buffer period and were excluded from the calculations. Soil respiration was calculated from the rate of increase of $\mathrm{CO}_{2}$ concentration in the measurement chamber in the remaining $1 \mathrm{~min}$ and $50 \mathrm{~s}$. The correlation coefficient of the linear relation between time and $\mathrm{CO}_{2}$ concentration was used as quality control, discarding values with $\mathrm{R}^{2}$ below 0.9 . Data were collected from 11 February to 17 November 2010 and from 14 February to 7 December 2011.

\subsection{Relationship between soil respiration and temperature}

Two models relating soil respiration to temperature were initially applied to the whole annual dataset of measurements obtained from each individual collar: the exponential $\left(Q_{10}\right)$ model

$R=B R \cdot Q_{10}^{\frac{T-T_{0}}{10}}$

and the Arrhenius-derived Lloyd and Taylor equation [6]. 


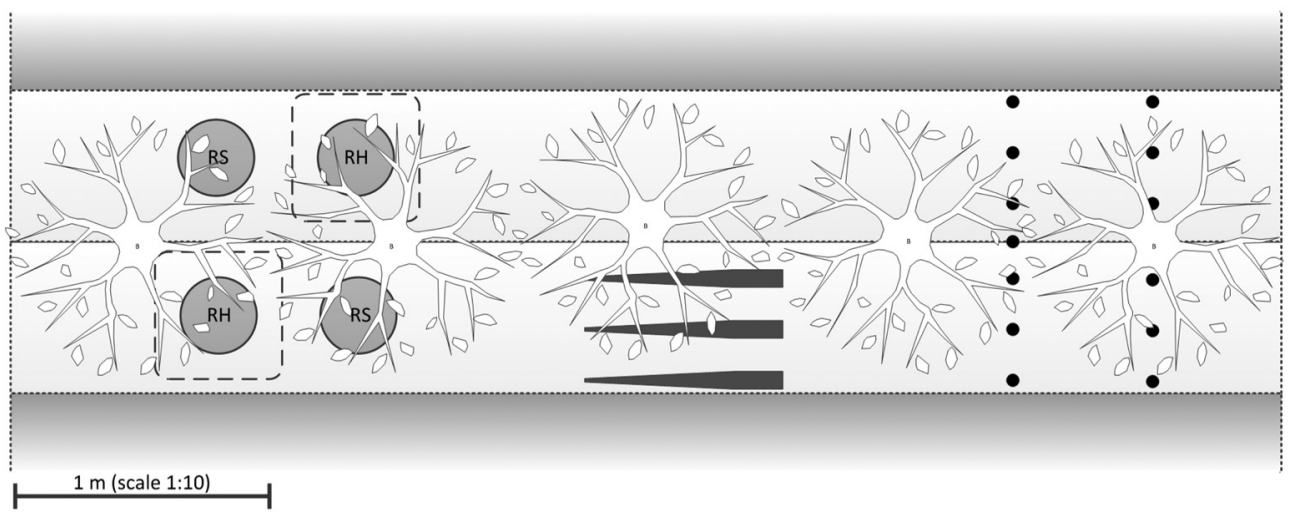

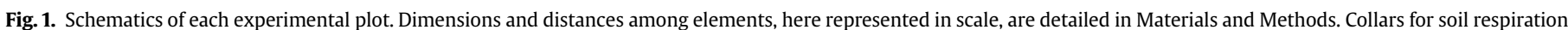

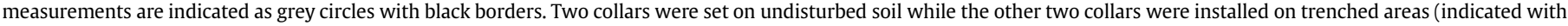

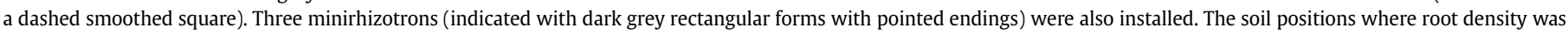
measured are represented by black dots.

$R=\operatorname{Rref} \cdot e^{E_{0} \cdot\left(0.0178507-\frac{1}{T+46.02}\right)}$

where $\mathrm{R}$ is the measured soil respiration rate $\left(\mu \mathrm{mol} \mathrm{m} \mathrm{m}^{-2} \mathrm{~s}^{-1}\right)$, BR is the basal respiration and Rref is respiration at the reference temperature at $10{ }^{\circ} \mathrm{C}, \mathrm{Q}_{10}$ and $\mathrm{E}_{0}$ describe the temperature $(\mathrm{T})$ dependence of the respiration. The comparison between these two models was performed by calculating for each collar the $\mathrm{R}^{2}$ adjusted for the degree of freedom, the root mean squared error (RMSE) and the mean absolute error (MAE) and performing a paired t-test. Using the Lloyd and Taylor model (Equation (2)) we obtained consistently slightly higher $\mathrm{R}^{2}$, lower root mean squared errors (RMSE) and the mean absolute errors (MAE) than when data were fitted according to the $\mathrm{Q}_{10}$ model (Equation (1); Table 1).

The missing values of soil respiration -for example those of winter months, when the system was withdrawn from the field for technical reasons- were gap-filled using the parameters Rref and $\mathrm{E}_{0}$ (Table 1) and applying Equation (2). The average and the relative uncertainty were calculated to obtain the total $\mathrm{R}_{\mathrm{S}}$ or $\mathrm{R}_{\mathrm{H}}$. To estimate total annual $R_{S}$ and $R_{H}$ the gap-filled time series of respiration data obtained from each non-trenched and from each trenched collars were respectively summed. Root respiration, $R_{R}$, was always calculated as difference between $R_{S}$ and $R_{H}$ while its error was estimated using the propagation of uncertainty.

\subsection{Tree photosynthesis, tree growth and environmental parameters}

Eddy covariance measurements of net ecosystem carbon exchange (NEE) were available at the site for the same period in which soil respiration measurements were taken. Full description of the eddy covariance set-up is reported in Zanotelli et al. [29,30]. Briefly, eddy covariance measurements were carried out in 2010 and 2011 using a LiCor 7000 (Lincoln, NE, USA) $\mathrm{CO}_{2} / \mathrm{H}_{2} \mathrm{O}$ analyser and a Gill R3 (Gill Instrument, Lymington, UK) sonic anemometer located $4 \mathrm{~m}$ above the tree canopy. Data were collected and computed with Eddysoft software [31]. Low quality data for turbulence and stationarity were screened out according to the Foken and Wichura quality test [32]. Gaps in data collection and flux values removed due to quality control concerns were filled with look-up tables (LUT) based on meteorological seasonal conditions. The observed data of NEE were used to assess gross primary productivity, GPP, by extrapolating daytime ecosystem respiration values for a bimonthly period from the nocturnal LUT according to air temperature and soil humidity for the specific daytime half-hour period.

Photosynthetic active radiation (PPFD) was measured by a PAR quantum sensor (Skye Instruments Ltd, Powys, United Kingdom), air temperature (Tair) at $8 \mathrm{~m}$ by CS215 (Campbell Scientific Incorporated, Logan, Utah, United States; CSI hereafter), and soil water content inside and outside the trenched areas by multiple TDRs (CS616, CSI). All meteorological data were recorded by a CR3000 (CSI).

Net primary productivity (NPP) was assessed biometrically during the growing seasons of 2010 and 2011 with a monthly frequency (8 sampling dates from April to November in both years). Six ecosystem components (above and belowground woody structure, fruits, leaves, fine roots and the herbaceous groundcover) were considered and quantified separately as described by Zanotelli et al. $[29,30]$. Total NPP was obtained by the sum of all the measured components in each sampling date.

Table 1

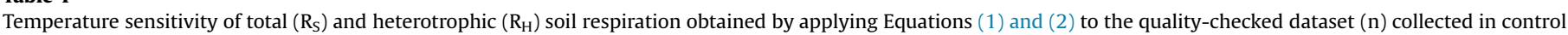

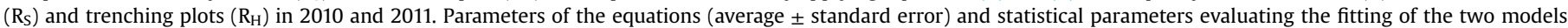
(adjusted $\mathrm{R}^{2}$, RMSE and MAE) are reported.

\begin{tabular}{|c|c|c|c|c|c|c|c|c|}
\hline & & \multirow[t]{2}{*}{$\mathrm{n}^{*}$} & \multicolumn{3}{|l|}{$\mathrm{Q}_{10}$ model } & \multicolumn{3}{|l|}{ Lloyd and Taylor model } \\
\hline & & & $\mathrm{BR}\left(\mu \mathrm{mol} \mathrm{CO} \mathrm{m}^{-2} \mathrm{~s}^{-1}\right)$ & $\mathrm{Q}_{10}$ (unitless) & Adjusted $\mathrm{R}^{2}(\%)$ & $\operatorname{Rref}\left(\mu \mathrm{mol} \mathrm{CO} \mathrm{Cm}^{-2} \mathrm{~s}^{-1}\right)$ & $\mathrm{E}_{0}(\mathrm{~K})$ & Adjusted $\mathrm{R}^{2}(\%)$ \\
\hline \multirow[t]{2}{*}{2010} & $\mathrm{R}_{\mathrm{S}}$ & 3708 & $2.62 \pm 0.21$ & $1.78 \pm 0.07$ & 0.400 & $2.39 \pm 0.21$ & $261.25 \pm 18.82$ & 0.410 \\
\hline & $\mathrm{R}_{\mathrm{H}}$ & 3514 & $1.41 \pm 0.13$ & $1.84 \pm 0.13$ & 0.440 & $1.28 \pm 0.13$ & $271.12 \pm 36.58$ & 0.450 \\
\hline \multirow[t]{5}{*}{2011} & $\mathrm{R}_{\mathrm{S}}$ & 5561 & $2.09 \pm 0.33$ & $1.68 \pm 0.04$ & 0.440 & $2.03 \pm 0.32$ & $211.92 \pm 17.38$ & 0.460 \\
\hline & $\mathrm{R}_{\mathrm{H}}$ & 6746 & $1.21 \pm 0.08$ & $1.62 \pm 0.02$ & 0.660 & $1.20 \pm 0.08$ & $200.17 \pm 6.73$ & 0.700 \\
\hline & & & & & & & & p-value \\
\hline & RMSE $^{* *}$ & & $1.47 \pm 0.10$ & & & $1.44 \pm 0.10$ & & $<0.0001$ \\
\hline & $\mathrm{MAE}^{* *}$ & & $1.15 \pm 0.07$ & & & $1.11 \pm 0.07$ & & $<0.0001$ \\
\hline
\end{tabular}

*Average number of half-hour measurements; ${ }^{* *}$ RMSE $=$ root mean standard error, MAE = mean absolute error. 
Tree root density was evaluated by soil coring with a cylindrical auger in several positions of the same orchard, outside the experimental parcels. Soil cores were collected in March 2010, before the beginning of vegetative growth, under six randomly chosen trees. Soil cores were sampled at $15,35,55 \mathrm{~cm}$ from the trees on both sides of the tree row to minimize any potential effect of north-south orientation, in line with the trunk and between two trunks (Fig. 1). Roots were divided in fine and coarse based on the threshold diameter of $2 \mathrm{~mm}$. Since the soil underneath trees was regularly weeded, we assumed that all the roots collected within this area belonged to apple trees. Soil core sampling was performed up to a depth of $60 \mathrm{~cm}$. Roots were separated from soil by wet sieving, dried in oven at $65{ }^{\circ} \mathrm{C}$ and weighted.

Root growth was assessed by image analysis. Minirhizotrons were installed in summer 2009. Transparent acrylic tubes $110 \mathrm{~cm}$ long and $7 \mathrm{~cm}$ wide were inserted into the soil profile with $45^{\circ}$ inclination angle, parallel to the tree row and at a distance of 15, 35 and $55 \mathrm{~cm}$ from trunks (Fig. 1). This setting allowed to measure root growth up to a depth of $60 \mathrm{~cm}$. After a first screening of the collected images, 8 representative minirhizotrons were considered for the analysis. Images of roots were taken at a $300 \mathrm{dpi}$ resolution with a root scanner (CI-600; CID BioScience, WA, USA), every 2-4 weeks, depending on the season, from 27 January to 12 November 2010 and from 4 February to 30 November 2011. Each image had a surface of $415.63 \mathrm{~cm}^{2}$. Image analysis was performed with the dedicated software WinRHIZO (Regent Instruments Inc., Canada). Each time and for each image, root length and average diameter area were measured and the root volume was calculated assuming roots as cylindrical. The data obtained from images taken at different depths were summed and the data from the three distances from the trunk $(15,35$ and $55 \mathrm{~cm})$ were averaged.

\subsection{Integration of photosynthetic activity into a model and statistics}

Data of total NPP were divided by the number of days between each sampling date to obtain the average daily NPP along the season. Similarly, average data of daily GPP, PPFD and Tair were calculated for the same periods as NPP. Equation (2) was applied to the measured $R_{S}$ and $R_{H}$ data in the same time slots, obtaining a set of Rref and $E_{0}$ parameters for $R_{S}$ ( $R_{S} r e f$ ) and $R_{H}$ ( $R_{H} r e f$ ). $R_{R}$ ref was obtained by difference between $R_{S} r e f$ and $R_{H}$ ref. A ranged major axis (RMA) linear regression was applied to Rref as a function of the average daily GPP, NPP, PPFD and Tair measured in the same period. This method was chosen to avoid the drawback of the ordinary least square regression method occurring when both variables are affected by errors, such as the asymmetry of parameter estimation and the underestimation of the slope parameter. To account for the photosynthetic activity of the plant throughout the growing season and therefore to produce an improved model to estimate $R_{S}$ and $R_{H}$, four new models were produced substituting Rref in Equation (2) with the parameters of the linear equation relating GPP, NPP, PPFD or Tair to $\mathrm{R}_{\mathrm{S}}$ or $\mathrm{R}_{\mathrm{H}}$ :

$R=(a+b x) \cdot e^{E_{0} \cdot\left(0.0178507-\frac{1}{T+46.02}\right)}$

where $a$ and $b$ represent respectively the intercept (expressed in $\mathrm{g} \mathrm{C} \mathrm{m}^{-2} \mathrm{day}^{-1}$ ) and the slope of the linear regression between RSref or $R_{H}$ ref and the daily values of $x$, where $x$ is either GPP, NPP, PPFD or Tair. This latter parameter -reintroducing temperature in Equation 2- highlights the correlation existing between the seasonal trend of photosynthesis and temperature. A single $\mathrm{E}_{0}$ parameter, average of 2010 and 2011, was used. A fifth model was used considering Equation (2) and a fixed Rref value obtained as the average of Rref in 2010 and Rref in 2011 (later referred as L\&T).
The five models obtained with 2010-11 data were tested against measured respiration data collected in 2012 in the same field. Only those days (for a total of 69 days) when all 48 half-hour data for both $R_{S}$ and $R_{H}$ were available were used to check the model. A major axis (MA) regression of the predicted vs. observed values was calculated together with its upper and lower $95 \%$ confidence interval, and the hypothesis of intercept $=0$ and slope $=1$ was tested for each model using the standardized major axis (SMA) function [33]. Additionally, the root mean squared deviation (RMSD) was calculated for each model, assessing the mean deviation (in $\mathrm{g} \mathrm{C} \mathrm{m}^{-2} \mathrm{day}^{-1}$ ) of predicted values respect to the observed ones.

A cross correlation analysis ("ccf" function from the R statistical computing environment [33]) was applied to the half-hour time series of GPP and $R_{R}$ at monthly time-step to check the existence of a correlation between the two fluxes and to assess the time lag between the two diurnal flux patterns.

The statistical analyses were performed with StatGraphics Centurion XV and with the software R [33].

\section{Results}

\subsection{Soil $\mathrm{CO}_{2}$ fluxes}

An example of data fitting according to the Lloyd and Taylor model is reported in Fig. 2 for soil respiration, $\mathrm{R}_{\mathrm{S}}$, and heterotrophic respiration, $R_{H}$. $R_{S}$ had maximum fluxes of $15 \mu \mathrm{mol} \mathrm{CO} \mathrm{Cm}^{-2} \mathrm{~s}^{-1}$, while $R_{H}$ had maximum fluxes of around $6 \mu \mathrm{mol} \mathrm{CO}_{2} \mathrm{~m}^{-2} \mathrm{~s}^{-1}$ (Fig. 2). In both years, air temperature explained less than $50 \%$ of the variability of $R_{S}$ data, while it explained a higher percentage of $\mathrm{R}_{\mathrm{H}}$ (Table 1). Despite the apparently lower fluxes of 2010 respect to 2011, the total annual $R_{S}$ was not statistically different between the two years $\left(1182.19 \pm 78.49\right.$ and $980.69 \pm 171.16 \mathrm{~g} \mathrm{C} \mathrm{m}^{-2}$ year $^{-1}$, respectively). On an annual basis and for both years, $\mathrm{R}_{\mathrm{H}}$ was $56-57$ $\%$ of $R_{S}$ (data not shown).

Soil respiration at reference temperature, Rref, increased in spring and early summer to reach a peak in summer (Fig. 3e and f). Values of the two years were similar in magnitude, with the exception of the peak recorded in July, higher in 2010 than in 2011. A marked decrease of Rref was then measured in autumn. In spring the Rref of the root component ( $R_{R} r e f$ ) was similar (in 2010) or lower (in 2011) than the Rref of the heterotrophic component ( $R_{H}$ ref), but then $R_{R}$ ref increased and in summer was similar or even higher than $R_{H}$ ref. In autumn, $R_{R}$ ref decreased more sharply than $R_{H}$ ref.

The seasonal trend of the $E_{0}$ parameter was similar for $R_{S}$ and $R_{H}$ although in 2010 it was more variable than in 2011 for both $R_{S}$ and $\mathrm{R}_{\mathrm{H}}$ (Fig. $3 \mathrm{~g}$ and $\mathrm{h}$ ). $\mathrm{E}_{0}$ increased from mid-February to mid-May when it reached its maximum. After this date, $E_{0}$ steadily declined until the end of the vegetative season.

\subsection{Relationship between photosynthesis and root respiration at diurnal scale}

While GPP showed a great variation within the day, with a peak in the central part of the day, root respiration varied only slightly (Fig. $4 a$ and b). The daily course of GPP and $R_{R}$ in each month showed a time lag between the two fluxes with GPP leading $R_{R}$. As shown in Table 2, from April to September the maximum correlation coefficients between $R_{R}$ and GPP (from 0.65 to 0.78 ) were found with a time delay of $2.5-3 \mathrm{~h}$ of $\mathrm{R}_{\mathrm{R}}$ respect to GPP. In October of both years, the highest correlation coefficients corresponded to a time delay of $1.5 \mathrm{~h}$. An example of the cross correlation analysis (ccf) analysis between GPP and $R_{R}$ in August and October is reported in Fig. $4 \mathrm{c}$ and d. 

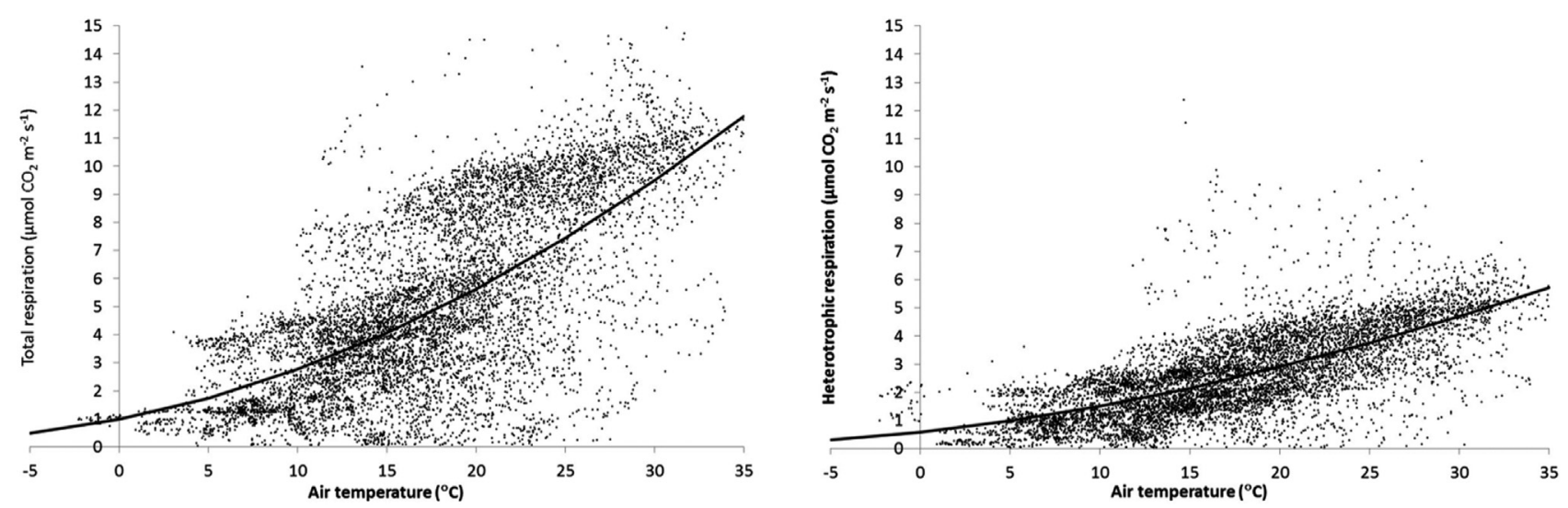

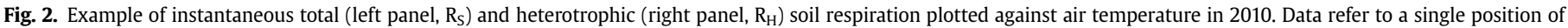
measurement. The lines indicate the curve obtained by applying the Lloyd and Taylor model (Equation (2)).

\subsection{Relationship between tree growth, photosynthesis and environmental parameters, and Rref at annual scale}

The GPP and NPP patterns across the season approached a bell shape, with maximum values between late spring and the end of summer, when both PPFD and Tair were highest (Fig. 3). More GPP, but not NPP, was produced in the second half of the year (from July on) than in the first half.

Root density was highly variable depending on where the soil core was sampled (Table 3). North or south orientation had no significant effect on root density therefore only their average is reported in Table 3. Coarse roots had higher density than fine roots up to $40 \mathrm{~cm}$ from the tree row, while the fine root biomass was higher than coarse root at $60 \mathrm{~cm}$ from the tree row. Fine root density, but not coarse root density, linearly decreased at increasing distances from the tree row.

Root growth rate was higher in 2011 than in 2010 (Fig. 3c and d). In both years root growth rate increased after winter and the highest values were measured in late spring-early summer. Root growth rate decreased in late summer-early autumn and it increased again in October (Fig. 3).

Significant linear relationships between the Rref calculated for $R_{S}, R_{H}$ and $R_{R}$ and GPP, NPP, PPFD and Tair were found (Fig. 5 and Table 4). Intercept values were always higher when $R_{H}$ was used as dependent variables than when $R_{R}$ was used (Table 4 ). At increasing values of GPP, NPP, PPFD and Tair, the spread between $R_{H}$ ref and $\mathrm{R}_{\mathrm{R}}$ ref decreased. $\mathrm{R}_{\mathrm{R}}$ ref became greater than $\mathrm{R}_{\mathrm{H}}$ ref at daily NPP values higher than $5.2 \mathrm{~g} \mathrm{C} \mathrm{m}^{-2} \mathrm{~d}^{-1}$, at average daily Tair higher than $20.8{ }^{\circ} \mathrm{C}$, at PPFD higher than $36.7 \mathrm{~mol} \mathrm{~m}^{-2} \mathrm{~d}^{-1}$, and with GPP approaching $9.2 \mathrm{~g} \mathrm{C} \mathrm{m}^{-2} \mathrm{~d}^{-1}$.

All relations between the data observed in 2012 and the predicted counterpart calculated using Equation (3) were significant (Fig. 6 and Table 5). However, some models predicted the measured data better than others did. For $R_{S}$, both hypotheses of intercept $=0$ and a slope $=1$ were verified only when PPFD was used in addition to Tair (Fig. 6c). When GPP was used as additional predictor, predicted and measured data were well correlated (Table 5), although observed data were overestimated at low respiration rates and underestimated at high respiration rates (Fig. 6a). Interestingly, GPP was the best additional predictor of $\mathrm{R}_{\mathrm{H}}$ as the intercept was not different from 0 and the slope was only barely significant (Table 5 and Fig. 6f). Tair also appeared to be a relatively good additional predictor for $\mathrm{R}_{\mathrm{H}}$ as the intercept was not different from 0 (Table 5 and Fig. $6 \mathrm{i}$ ). In all the other cases both hypotheses that the intercept is 0 and that the slope is 1 had to be rejected due to highly significant $\mathrm{p}$ values, indicating a low capacity of the models to predict respiration with accuracy (Table 5).

\section{Discussion}

The average temperature of the air explained a significant fraction of the variability of total soil respiration, ranging from 40 to $46 \%$ and slightly variable according to the year and the model used ( $Q_{10}$ and Lloyd and Taylor). Using both models, temperature alone explained a higher degree of variability of $R_{H}$ than of $R_{S}$ (especially in $2011, \mathrm{R}^{2}=0.66-0.70$ ) a fact suggesting that factors different from temperature had a higher control on total soil respiration $\left(R_{R}+R_{H}\right)$ than on $R_{H}$ alone. Both models showed a coherent picture, with $R_{H}$ at the reference temperature of $10{ }^{\circ} \mathrm{C}$ representing between 53 and $59 \%$ of total $\mathrm{R}_{\mathrm{S}}$ (Table 1), a proportion reported also in other ecosystems [34], although cases where autotrophic respiration slightly exceeding heterotrophic respiration are also reported [35,36]. The $\mathrm{Q}_{10}$ for total soil respiration (1.8, Table 1 ) was close to the value of 1.72 reported as average of several ecosystems [37] and slightly lower than the value of 2.4 reported by Ceccon et al. [26] for an apple orchard.

Although important, temperature as solely predicting variable only partially explained the variability of soil respiration and could not be used alone to predict daily soil respiration in 2012 with a good accuracy (Table 5, Fig. 6). We therefore integrated the temperature-independent portion of soil respiration, represented by Rref, by adding to Equation (2) either the photosynthetic activity, represented by GPP, or the other main variables (PPFD, Tair and NPP) that covary with photosynthesis during the season (Fig. 3). A similar approach was proposed by Bahn et al. [16] to assess differences among ecosystems at annual scale, while the seasonality between dormant and growing season was approached by Ruehr and Buchmann [15]. In our study, there was a seasonal pattern of the total respiration at a reference temperature (Rsref, Fig. 3), typical of temperate tree ecosystems $[9,38]$ corresponding to that observed for GPP, NPP and root growth rate (Fig. 3). The dependence of soil respiration from the physiological activity of the trees is indicated by the degree of correlation between Rref and GPP, NPP, PPDF and Tair, recorded in different periods of the two years (Fig. 5, Table 4). A positive correlation of temperature-independent soil respiration and the photosynthetic active radiation and air temperature was also found by Liu and colleagues [39].

The contribution of $R_{R}$ to $R_{S}$ increased at increasing values of GPP, NPP, PPFD and Tair, as indicated by the slopes of the linear regressions reported in Fig. 5. Although not supported by specific 

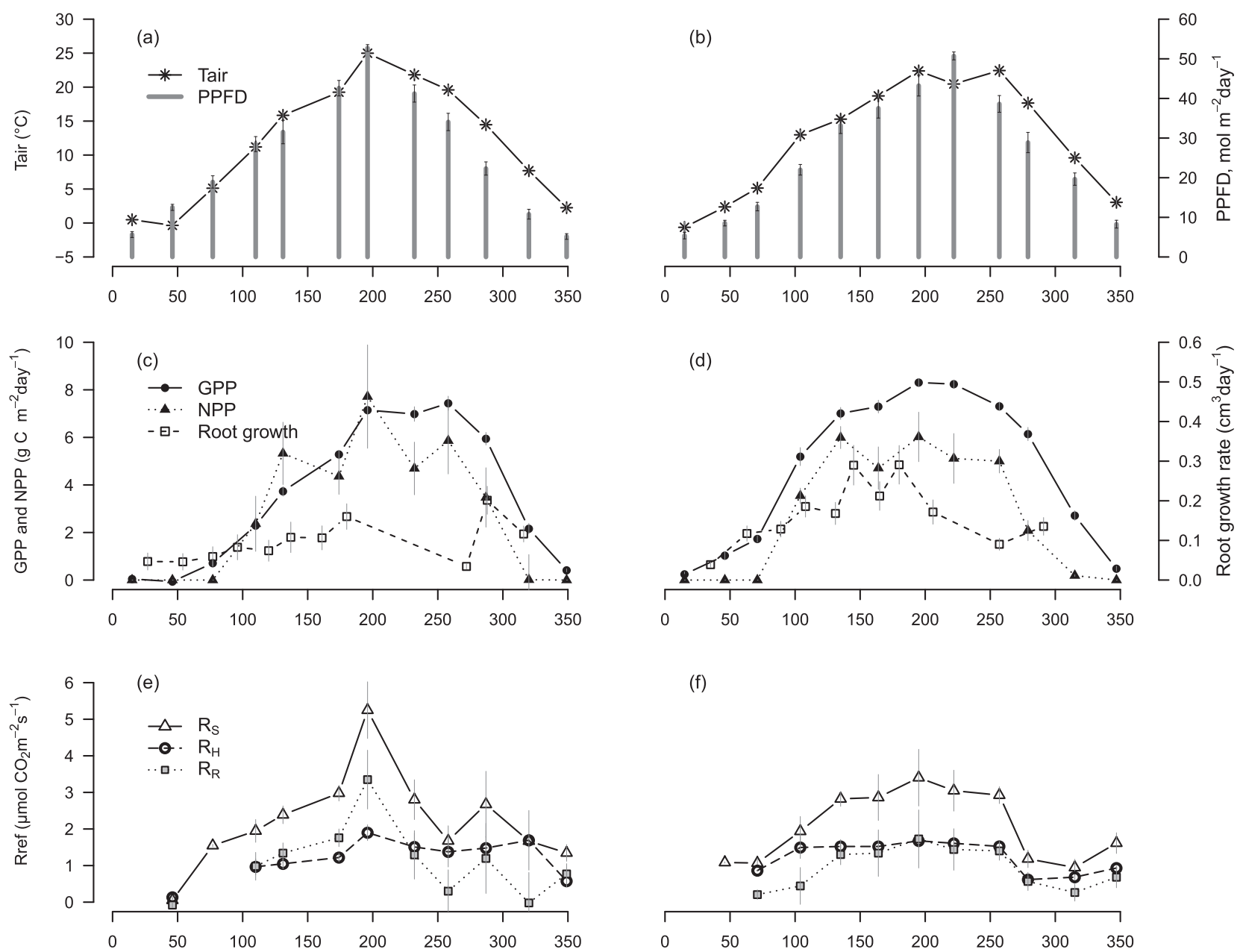

(f)
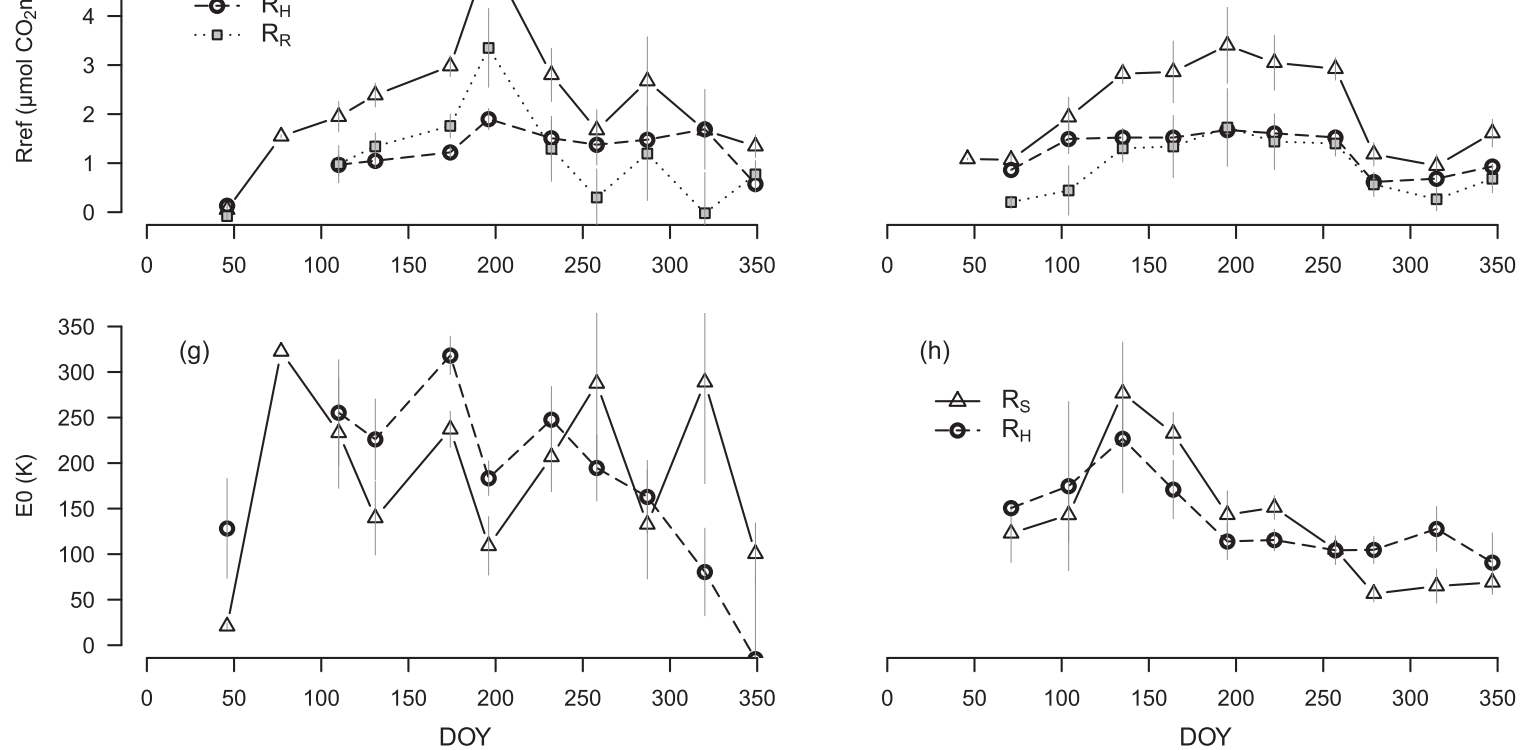

(h)

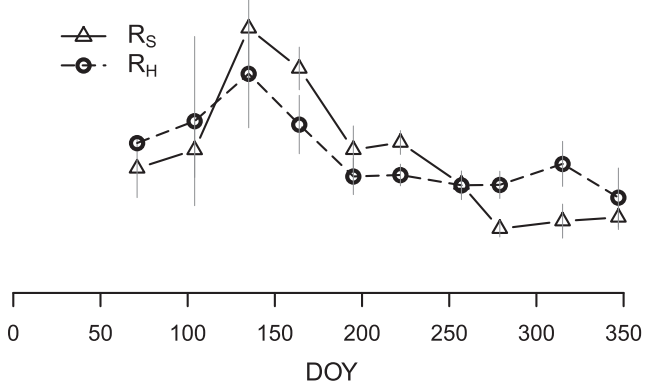

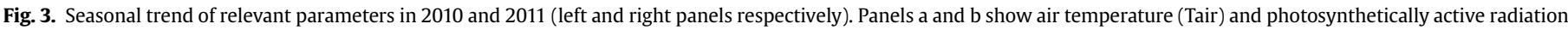

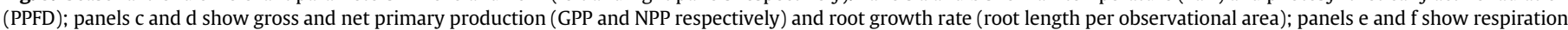
at a reference temperature of $10{ }^{\circ} \mathrm{C}$ (Rref); panels g and h show $\mathrm{E}_{0}$. Bars represent the standard error.

statistical analysis, it is worthy to note that the highest values of $\mathrm{R}_{\mathrm{R}}$ ref were recorded after roots had reached their highest growth rate (Fig. 3). This is in line with the assumption that tree root density affects root respiration rate [14,26]. The root dynamics also contribute to explain the changes of root respiration over the season, as it includes components with different temporal dynamics such as ion uptake, maintenance and growth respiration [40,41].

In Equation (3), the parameter $\mathrm{E}_{0}$ we used was the average of the two years to avoid the confounding effect due to its variability evident especially in 2010 (Fig. 3g). We are aware that this procedure might have led to an under- or an over-estimation of the predicted values as suggested by Reichstein et al. [12], who demonstrated that $\mathrm{E}_{0}$ is lower when calculated for sub-periods and then averaged than when calculated for a single longer period. To test to which extent our assumption could have led to estimation errors of the predicted values, we applied Equation (3) also by using arbitrary values of $E_{0}$ included between 50 and $300 \mathrm{~K}$ at step increments of $50 \mathrm{~K}$. We found that the total amount of soil and heterotrophic respiration is indeed affected by the value of $E_{0}$, but that the overall predicting power of Equation (3) does not change substantially when compared to measured data (data not shown).

The evidences reported in our study suggest that at yearly scale, 

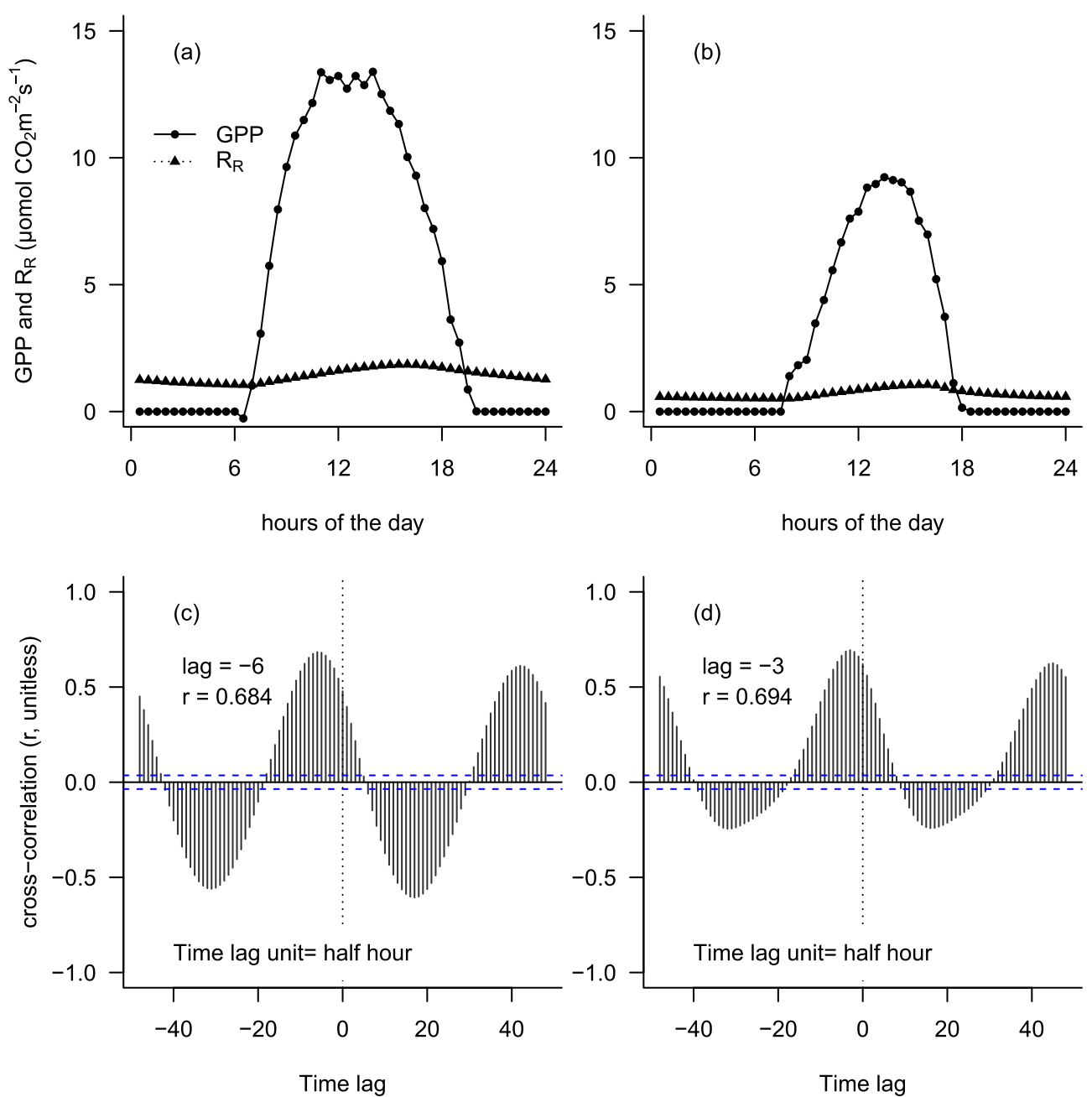

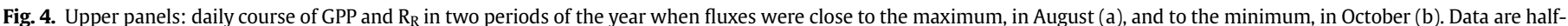

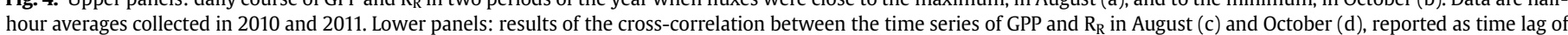
half hours ( \pm 48 half hours are reported). The y-axis indicates the normalized correlation coefficient, $\mathrm{r}$. The complete cross correlation analysis is reported in Table 2.

Table 2

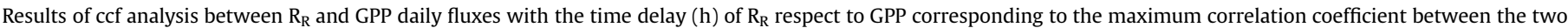
fluxes.

\begin{tabular}{|c|c|c|c|c|}
\hline \multirow[t]{2}{*}{ Month } & \multicolumn{2}{|l|}{2010} & \multicolumn{2}{|l|}{2011} \\
\hline & Maximum value of correlation coefficient, $r$ & Time delay (h) & Maximum value of correlation coefficient, $r$ & Time delay (h) \\
\hline April & 0.723 & 2.5 & 0.784 & 2.5 \\
\hline May & 0.720 & 2.5 & 0.755 & 2.5 \\
\hline June & 0.651 & 2.5 & 0.686 & 2.5 \\
\hline July & 0.723 & 2.5 & 0.732 & 3 \\
\hline August & 0.711 & 2.5 & 0.746 & 3 \\
\hline September & 0.732 & 2.5 & 0.753 & 2.5 \\
\hline October & 0.675 & 1.5 & 0.742 & 1.5 \\
\hline
\end{tabular}

Table 3

Apple root density at different distances from the tree trunk. Data, reported as dry weight in $\mathrm{kg} \mathrm{m}^{-3}$, refer to the first $60 \mathrm{~cm}$ of soil depth (average \pm standard error).

\begin{tabular}{|c|c|c|c|c|}
\hline \multirow[t]{3}{*}{ Distance from tree row $(\mathrm{cm})$} & \multicolumn{2}{|l|}{ Coarse roots } & \multicolumn{2}{|l|}{ Fine roots } \\
\hline & \multicolumn{2}{|l|}{ Sampling position } & \multicolumn{2}{|l|}{ Sampling position } \\
\hline & Perpendicular to the tree trunk & Between trees & Perpendicular to the tree trunk & Between trees \\
\hline 0 & - & $1.02 \pm 0.45$ & - & $0.51 \pm 0.13$ \\
\hline 20 & $5.37 \pm 1.25$ & $2.43 \pm 1.69$ & $0.86 \pm 0.11$ & $0.49 \pm 0.08$ \\
\hline 40 & $1.16 \pm 0.33$ & $0.72 \pm 0.4$ & $0.55 \pm 0.07$ & $0.38 \pm 0.05$ \\
\hline 60 & $0.16 \pm 0.05$ & $0.19 \pm 0.06$ & $0.31 \pm 0.03$ & $0.28 \pm 0.03$ \\
\hline
\end{tabular}



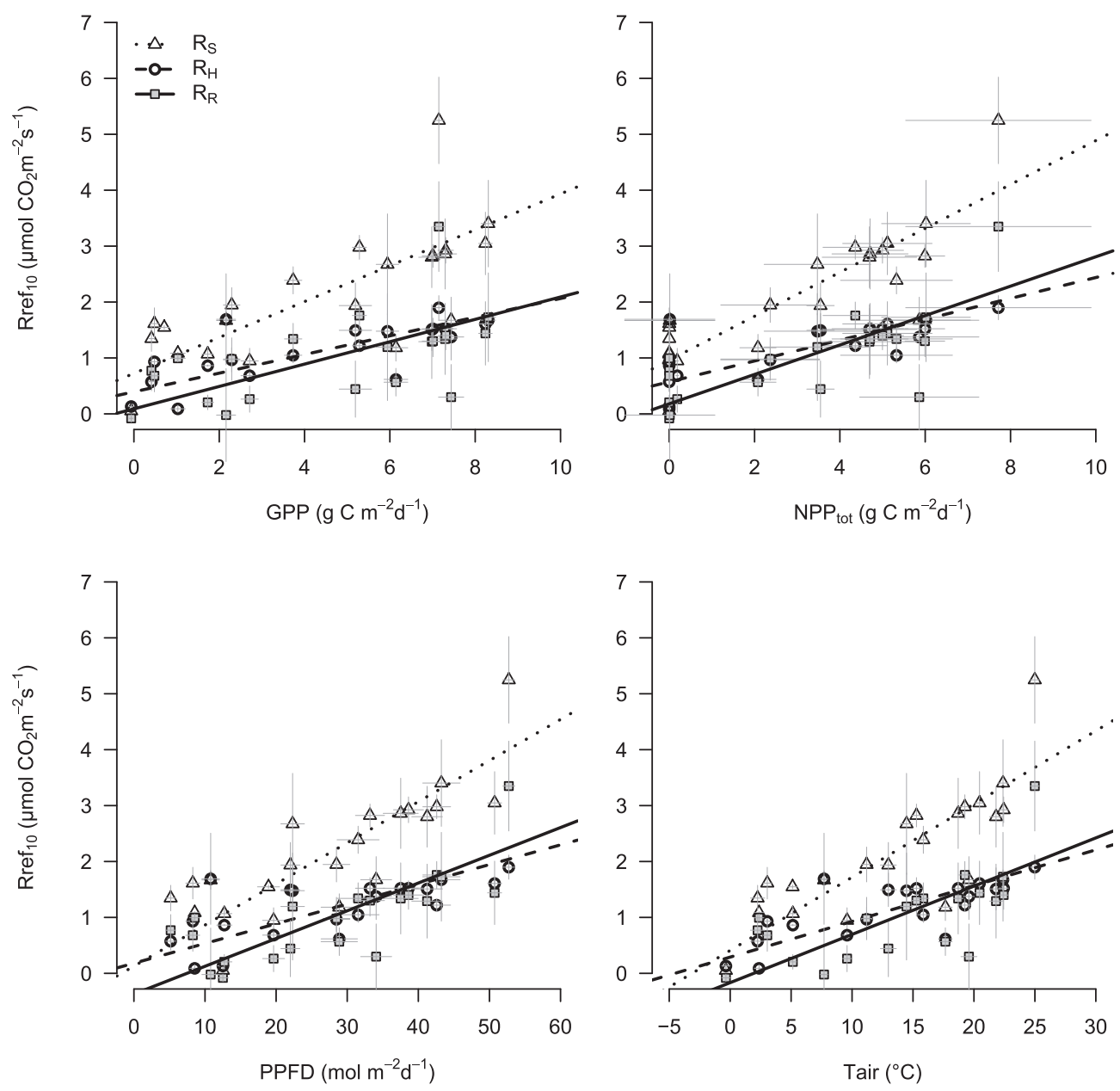

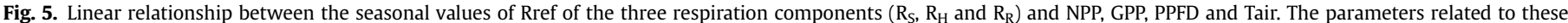
relations are reported in Table 4.

Table 4

Parameters of the relations shown in Fig. 5 between Rref and NPP, GPP, PPFD and Tair. 2-tailed significance of the individual relationships are shown. For additional details please check Table S1.

\begin{tabular}{llcccr}
\hline Driver & Rref & Intercept & Slope & $\mathrm{R}^{2}$ & p-value \\
\hline GPP & $\mathrm{R}_{\mathrm{S}}$ & 0.724 & 0.321 & 0.528 & 0.0001 \\
& $\mathrm{R}_{\mathrm{H}}$ & 0.394 & 0.167 & 0.576 & 0.0001 \\
& $\mathrm{R}_{\mathrm{R}}$ & 0.090 & 0.200 & 0.310 & 0.0088 \\
& & & & & \\
NPP & $\mathrm{R}_{\mathrm{S}}$ & 0.960 & 0.393 & 0.705 & $<0.0001$ \\
& $\mathrm{R}_{\mathrm{H}}$ & 0.573 & 0.187 & 0.551 & 0.0001 \\
& $\mathrm{R}_{\mathrm{R}}$ & 0.179 & 0.263 & 0.543 & 0.0001 \\
& & & & & \\
PPFD & $\mathrm{R}_{\mathrm{S}}$ & 0.128 & 0.074 & 0.669 & $<0.0001$ \\
& $\mathrm{R}_{\mathrm{H}}$ & 0.181 & 0.035 & 0.458 & 0.0008 \\
& $\mathrm{R}_{\mathrm{R}}$ & -0.370 & 0.050 & 0.547 & $<0.0001$ \\
& & & & & \\
Tair & $\mathrm{R}_{\mathrm{S}}$ & 0.409 & 0.131 & 0.652 & $<0.0001$ \\
& $\mathrm{R}_{\mathrm{H}}$ & 0.290 & 0.064 & 0.577 & 0.0001 \\
& $\mathrm{R}_{\mathrm{R}}$ & -0.167 & 0.086 & 0.452 & 0.0008 \\
\hline
\end{tabular}

root respiration is affected by the tree availability of carbohydrates, which most likely affects the amount of $C$ allocated to the root system [19]. The effects of tree photosynthesis on root respiration is also supported by the covariation of root respiration and photosynthesis data found at daily scale, where a time lag of $1.5-3.0 \mathrm{~h}$ was recorded (Table 2 and Fig. 4), consistently with previous reports $[42,43]$. The fact that photosynthesis provides an important and immediate $C$ source to roots was proved in grasslands by the use of stabile isotope technique [16]. Interestingly, the time lag between the two time series was between 2.5 and $3 \mathrm{~h}$ from March to September, but decreased to $1.5 \mathrm{~h}$ in October and November. Since fruits represent approximately $50 \%$ of NPP [30] and represent a strong sink of $\mathrm{C}$ assimilates, this reduction of time lag between fixed and respired $C$ in the late part of the season may be related to their removal at the harvest time.

Interestingly, not only root respiration but also heterotrophic respiration was affected by tree activity as indicated by the fact that also $R_{H}$ ref increased at increasing values of GPP, NPP, PPDF and Tair (Fig. 4) and by the fact that GPP was the best additional predictor of $R_{H}$ in 2012 (Table 5). Although it has been already reported that heterotrophic respiration could be directly affected by GPP through the decomposition of dead roots and leaf litter [44], this explanation does not apply to our experiment because $R_{H}$ was measured in plots where no roots should have been present. We hypothesize that this finding might be related to the presence of root-associated mycorrizhal fungi in the trenched plots, whose respiration depends on the availability of $C$ assimilates $[19,45]$. Another explanation might rely on the multicollinearity existing between plant activity and microbial activity during the season. Further investigation is needed to confirm these hypotheses.

The results shown in Fig. 6 clearly demonstrate that the Lloyd and Taylor model has a relatively low prediction power of soil 
Table 5

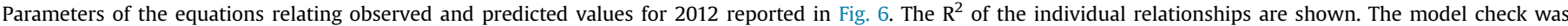

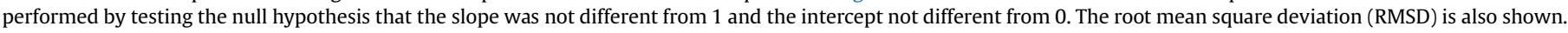
For additional details please check Table S2.

\begin{tabular}{|c|c|c|c|c|c|c|c|}
\hline & & \multirow[t]{2}{*}{ Intercept } & \multirow[t]{2}{*}{ Slope } & \multirow[t]{2}{*}{$\mathrm{R}^{2}$} & \multicolumn{3}{|l|}{ Model check } \\
\hline & & & & & $\begin{array}{l}\mathrm{p} \text {-value of } \mathrm{H} 0 \text { testing } \\
\text { for intercept }=0\end{array}$ & $\begin{array}{l}\mathrm{p} \text {-value of } \mathrm{H} 0 \text { testing } \\
\text { for slope }=1\end{array}$ & RMSD \\
\hline \multirow[t]{2}{*}{ GPP } & $\mathrm{R}_{\mathrm{S}}$ & 1.531 & 0.565 & 0.673 & $<0.0001$ & $<0.0001$ & 1.312 \\
\hline & $\mathrm{R}_{\mathrm{H}}$ & 0.178 & 1.194 & 0.679 & 0.2688 & 0.0377 & 0.614 \\
\hline \multirow[t]{2}{*}{ NPP } & $\mathrm{R}_{\mathrm{S}}$ & 2.728 & 0.241 & 0.322 & $<0.0001$ & $<0.0001$ & 1.828 \\
\hline & $\mathrm{R}_{\mathrm{H}}$ & 0.956 & 0.644 & 0.589 & $<0.0001$ & $<0.0001$ & 0.569 \\
\hline \multirow[t]{2}{*}{ PPFD } & $\mathrm{R}_{\mathrm{S}}$ & 0.329 & 0.829 & 0.568 & 0.3928 & 0.0807 & 1.472 \\
\hline & $\mathrm{R}_{\mathrm{H}}$ & -0.691 & 1.723 & 0.585 & 0.0163 & $<0.0001$ & 0.721 \\
\hline \multirow[t]{2}{*}{ Tair } & $\mathrm{R}_{\mathrm{S}}$ & 1.848 & 0.586 & 0.339 & $<0.0001$ & 0.0016 & 1.782 \\
\hline & $\mathrm{R}_{\mathrm{H}}$ & 0.017 & 1.425 & 0.563 & 0.9432 & 0.0013 & 0.839 \\
\hline \multirow[t]{2}{*}{ L\&T } & $\mathrm{R}_{\mathrm{S}}$ & 2.725 & 0.222 & 0.338 & $<0.0001$ & $<0.0001$ & 1.845 \\
\hline & $\mathrm{R}_{\mathrm{H}}$ & 1.060 & 0.634 & 0.591 & $<0.0001$ & $<0.0001$ & 0.637 \\
\hline
\end{tabular}
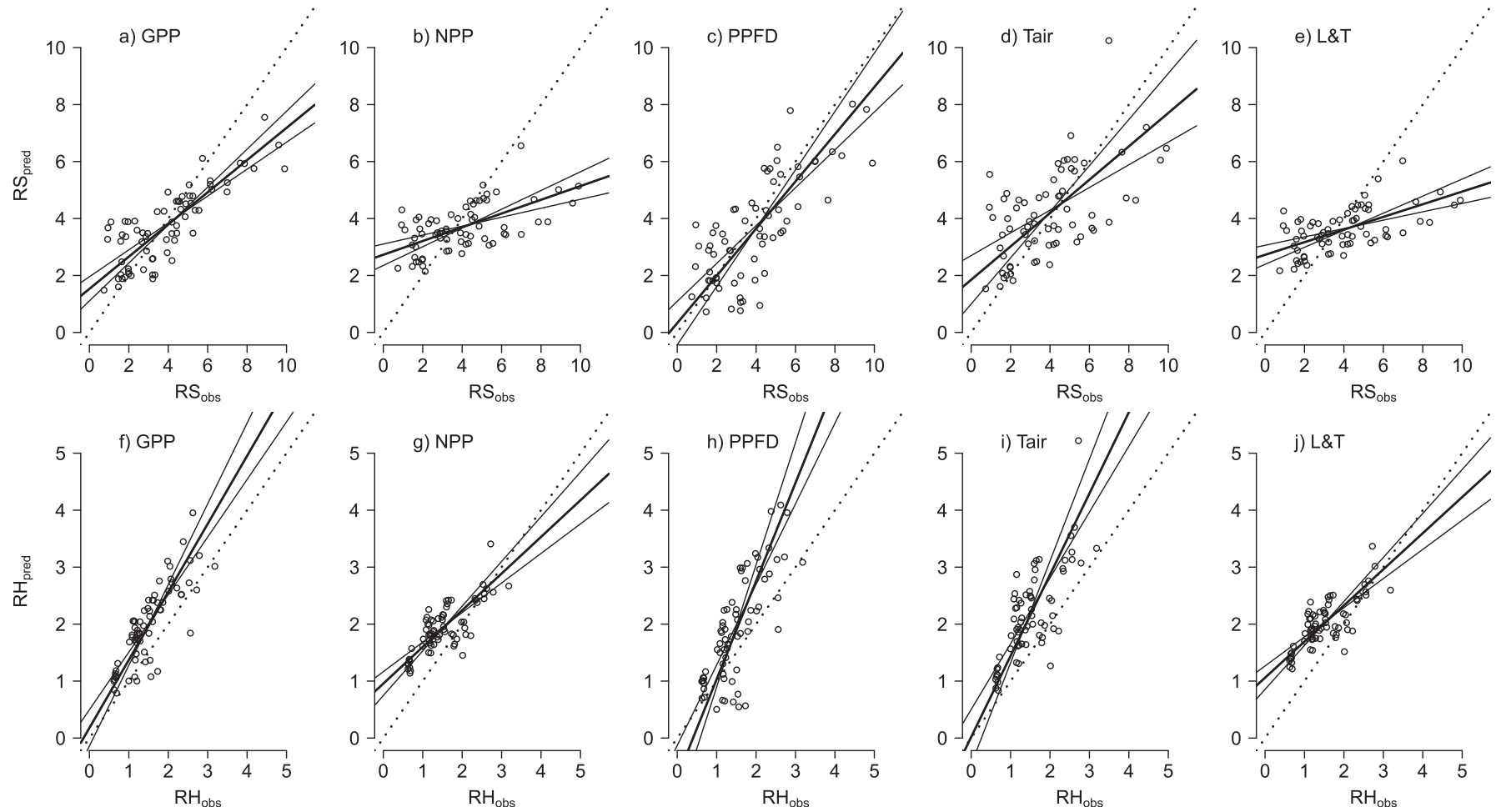

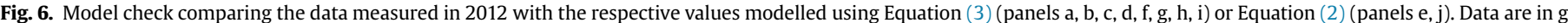

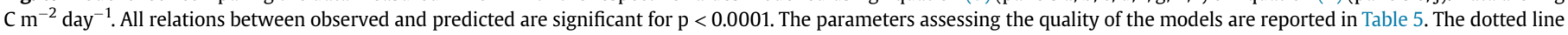
indicates the identity line.

respiration at a daily rate, while the accuracy of prediction is improved if a proxy for photosynthesis such as PPFD is integrated in the model (Table 5). When we used GPP as additional predictor, the predicted values of soil respiration were highly correlated with the observed ones but the prediction was not accurate. This fact might be at least partially explained considering that in our study GPP values included not only the photosynthesis of the trees but also that derived from the herbaceous vegetation present in the orchard floor. Moreover, additional factors not considered in this study -such as the temporal variability of soil fertility and soil moisture due to mineral supply and irrigation - might have played a role in controlling the changes in soil respiration over the season.
In conclusion, we verified that less than $50 \%$ of the variability of soil respiration in an apple orchard was explained by temperature. Although temperature-related models to predict soil respiration at a local and global scale are very widespread, we demonstrated that including a proxy of tree photosynthesis, such as PPFD, into a temperature-based model increases the accuracy of the prediction of soil respiration in an apple orchard. This effect is likely due to the control of photosynthesis on C availability for the root system, whose contribution to total soil respiration increases with light regimes, GPP, NPP and temperature. Our results therefore support the C-assimilates-supply-to-roots theory and the need for a more eco-physiological perspective to understand soil respiration. 


\section{Acknowledgements}

The authors wish to thank Dr. Armin Otto Schmitt for his support in the statistical analysis of data. This study was carried out with the financial support from the Provincia Autonoma di Bolzano-Bozen through the project "Assessing the potential for $\mathrm{CO}_{2}$ sequestration by apple orchards in South Tyrol" (grant number TN5201), from the Free University of Bolzano-Bozen through the project "Quantification of net carbon ecosystem exchange in an apple orchard in South Tyrol" (grant number I41J11000600005), and from program Prin2008 of the Italian Minister of University through the project "Carbon fluxes in the apple orchard" (grant number 2008LX3AYP 001). Historic climatic data were retrieved from the meteorological service of the Provincia Autonoma di Bolzano-Bozen (http://www.provincia.bz.it).

\section{Appendix A. Supplementary data}

Supplementary data related to this article can be found at http:// dx.doi.org/10.1016/j.ejsobi.2015.07.006.

\section{References}

[1] J.W. Raich, W.H. Schlesinger, The global carbon dioxide flux in soil respiration and its relationship to vegetation and climate, Tellus B 44 (1992) 81-99, http://dx.doi.org/10.1034/j.1600-0889.1992.t01-1-00001.x.

[2] P. Hogberg, N. Buchmann, D. Read, Comments on Yakov Kuzyakov's review "Sources of CO2 efflux from soil and review of partitioning methods"[Soil Biology \& Biochemistry 38, 425-448], Soil Biol. Biochem. 38 (2006) 2997-2998, http://dx.doi.org/10.1016/j.soilbio.2006.04.001.

[3] Y. Kuzyakov, Sources of $\mathrm{CO}_{2}$ efflux from soil and review of partitioning methods, Soil Biol. Biochem. 38 (2006) 425-448, http://dx.doi.org/10.1016/ j.soilbio.2005.08.020.

[4] Y. Kuzyakov, Response to the comments by Peter Högberg, Nina Buchmann and David J. Read on the review "Sources of $\mathrm{CO}_{2}$ efflux from soil and review of partitioning methods" (Soil Biology \& Biochemistry 38, 425-448)Objectversus method-oriented terminology, Soil Biol. Biochem. 38 (2006) 2999-3000, http://dx.doi.org/10.1016/j.soilbio.2006.04.002.

[5] M. Tuomi, P. Vanhala, K. Karhu, H. Fritze, J. Liski, Heterotrophic soil respiration-comparison of different models describing its temperature dependence, Ecol. Model 211 (2008) 182-190, http://dx.doi.org/10.1016/ j.ecolmodel.2007.09.003.

[6] J. Lloyd, J.A. Taylor, On the temperature dependence of soil respiration, Funct. Ecol. 8 (1994) 315, http://dx.doi.org/10.2307/2389824.

[7] M. von Lützow, I. Kögel-Knabner, Temperature sensitivity of soil organic matter decomposition-what do we know? Biol. Fertil. Soils 46 (2009) 1-15, http://dx.doi.org/10.1007/s00374-009-0413-8.

[8] M. Khomik, M.A. Arain, K.-L. Liaw, J.H. McCaughey, Debut of a flexible model for simulating soil respiration-soil temperature relationship: Gamma model, J. Geophys. Res. 114 (2009), http://dx.doi.org/10.1029/2008JG000851.

[9] L.B. Flanagan, B.G. Johnson, Interacting effects of temperature, soil moisture and plant biomass production on ecosystem respiration in a northern temperate grassland, Agric. For. Meteorol 130 (2005) 237-253, http:// dx.doi.org/10.1016/j.agrformet.2005.04.002.

[10] J.-A. Subke, M. Bahn, On the "temperature sensitivity" of soil respiration: can we use the immeasurable to predict the unknown? Soil Biol. Biochem. 42 (2010) 1653-1656, http://dx.doi.org/10.1016/j.soilbio.2010.05.026.

[11] N. Gomez-Casanovas, K. Anderson-Teixeira, M. Zeri, C.J. Bernacchi, E.H. DeLucia, Gap filling strategies and error in estimating annual soil respiration, Glob. Change Biol. (2012), http://dx.doi.org/10.1111/gcb.12127 n/a-n/ a.

[12] M. Reichstein, E. Falge, D. Baldocchi, D. Papale, M. Aubinet, P. Berbigier, et al., On the separation of net ecosystem exchange into assimilation and ecosystem respiration: review and improved algorithm, Glob. Change Biol. 11 (2005) 1424-1439, http://dx.doi.org/10.1111/j.1365-2486.2005.001002.x.

[13] A.D. Richardson, B.H. Braswell, D.Y. Hollinger, P. Burman, E.A. Davidson, R.S. Evans, et al., Comparing simple respiration models for eddy flux and dynamic chamber data, Agric. For. Meteorol. 141 (2006) 219-234, http:// dx.doi.org/10.1016/j.agrformet.2006.10.010.

[14] M. Rodeghiero, A. Cescatti, Main determinants of forest soil respiration along an elevation/temperature gradient in the Italian Alps, Glob. Change Biol. 11 (2005) 1024-1041, http://dx.doi.org/10.1111/j.1365-2486.2005.00963.x.

[15] N.K. Ruehr, N. Buchmann, Soil respiration fluxes in a temperate mixed forest: seasonality and temperature sensitivities differ among microbial and root-rhizosphere respiration, Tree Physiol. 30 (2010) 165-176.

[16] M. Bahn, M. Rodeghiero, M. Anderson-Dunn, S. Dore, C. Gimeno, M. Drösler, et al., Soil respiration in European grasslands in relation to climate and assimilate Supply, Ecosystems 11 (2008) 1352-1367, http://dx.doi.org/10.1007/ s10021-008-9198-0.

[17] E.A. Davidson, I.A. Janssens, Y. Luo, On the variability of respiration in terrestrial ecosystems: moving beyond Q10, Glob. Change Biol. 12 (2006) 154-164, http://dx.doi.org/10.1111/j.1365-2486.2005.01065.x.

[18] M. Reichstein, A. Rey, A. Freibauer, J. Tenhunen, R. Valentini, J. Banza, et al., Modeling temporal and large-scale spatial variability of soil respiration from soil water availability, temperature and vegetation productivity indices, Glob. Biogeochem. Cycles 17 (2003), http://dx.doi.org/10.1029/2003GB002035 n/ $\mathrm{a}-\mathrm{n} / \mathrm{a}$.

[19] F. Hopkins, M.A. Gonzalez-Meler, C.E. Flower, D.J. Lynch, C. Czimczik, J. Tang, et al., Ecosystem-level controls on root-rhizosphere respiration, New Phytol. 199 (2013) 339-351, http://dx.doi.org/10.1111/nph.12271.

[20] J.-A. Subke, I. Inglima, M. Francesca Cotrufo, Trends and methodological impacts in soil $\mathrm{CO}_{2}$ efflux partitioning: a metaanalytical review, Glob. Change Biol. 12 (2006) 921-943, http://dx.doi.org/10.1111/j.13652486.2006.01117.x.

[21] P. Högberg, A. Nordgren, N. Buchmann, A.F.S. Taylor, A. Ekblad, M.N. Högberg et al., Large-scale forest girdling shows that current photosynthesis drives soil respiration, Nature 411 (2001) 789-792, http://dx.doi.org/10.1038/35081058.

[22] J. Amthor, The McCree-de Wit-Penning de Vries-Thornley respiration paradigms: 30 years later, Ann. Bot. 86 (2000) 1-20, http://dx.doi.org/10.1006/ anbo.2000.1175.

[23] J.T.A. Proctor, R.L. Watson, J.J. Landsberg, The carbon budget of a young apple tree, J. Am. Soc. Hortic. Sci. 101 (1976) 579-582.

[24] M.M. Blanke, Soil respiration in an apple orchard, Environ. Exp. Bot. 36 (1996) 339-348, http://dx.doi.org/10.1016/0098-8472(96)01003-9.

[25] A. Tufekcioglu, A.K. Ozbayram, M. Kucuk, Soil respiration in apple orchards, poplar plantations and adjacent grasslands in Artvin, Turkey, J. Environ. Biol. 30 (2009) 815.

[26] C. Ceccon, P. Panzacchi, F. Scandellari, L. Prandi, M. Ventura, B. Russo, et al., Spatial and temporal effects of soil temperature and moisture and the relation to fine root density on root and soil respiration in a mature apple orchard, Plant Soil 342 (2011) 195-206, http://dx.doi.org/10.1007/s11104-010-06848.

[27] D.M. Glenn, E. Campostrini, Girdling and summer pruning in apple increase soil respiration, Sci. Hortic. 129 (2011) 889-893.

[28] Y. Kuzyakov, A.A. Larionova, Root and rhizomicrobial respiration: a review of approaches to estimate respiration by autotrophic and heterotrophic organisms in soil, J. Plant Nutr. Soil Sci. 168 (2005) 503-520, http://dx.doi.org/ 10.1002/jpln.200421703.

[29] D. Zanotelli, L. Montagnani, G. Manca, M. Tagliavini, Net primary productivity, allocation pattern and carbon use efficiency in an apple orchard assessed by integrating eddy covariance, biometric and continuous soil chamber measurements, Biogeosciences 10 (2013) 3089-3108, http://dx.doi.org/10.5194/ bg-10-3089-2013.

[30] D. Zanotelli, L. Montagnani, G. Manca, F. Scandellari, M. Tagliavini, Net ecosystem carbon balance of an apple orchard, Eur. J. Agron. 63 (2015) 97-104, http://dx.doi.org/10.1016/j.eja.2014.12.002.

[31] O. Kolle, C. Rebman, Eddysoft-Documentation of a Software Package ToAcquire and Process Eddy Covariance Data Technical Reports, 2007.

[32] T. Foken, B. Wichura, Tools for quality assessment of surface-based flux measurements, Agric. For. Meteorol 78 (1996) 83-105, http://dx.doi.org/ 10.1016/0168-1923(95)02248-1.

[33] R. Core Team, R: a Language and Environment for Statistical Computing, R Foundation for Statistical Computing, Vienna, Austria, 2014. http://www.Rproject.org/.

[34] N. Gomez-Casanovas, R. Matamala, D.R. Cook, M.A. Gonzalez-Meler, Net ecosystem exchange modifies the relationship between the autotrophic and heterotrophic components of soil respiration with abiotic factors in prairie grasslands, Glob. Change Biol. 18 (2012) 2532-2545, http://dx.doi.org/ 10.1111/j.1365-2486.2012.02721.x.

[35] J. Ngao, B. Longdoz, A. Granier, D. Epron, Estimation of autotrophic and heterotrophic components of soil respiration by trenching is sensitive to corrections for root decomposition and changes in soil water content, Plant Soil 301 (2007) 99-110, http://dx.doi.org/10.1007/s11104-007-9425-z.

[36] D. Gaumont-Guay, T.A. Black, A.G. Barr, R.S. Jassal, Z. Nesic, Biophysical controls on rhizospheric and heterotrophic components of soil respiration in a boreal black spruce stand, Tree Physiol. 28 (2008) 161-171.

[37] T. Zhou, P. Shi, D. Hui, Y. Luo, Global pattern of temperature sensitivity of soil heterotrophic respiration (Q10) and its implications for carbon-climate feedback, J. Geophys. Res. 114 (2009), http://dx.doi.org/10.1029/ 2008JG000850.

[38] P.V. Bolstad, J.M. Vose, Forest and pasture carbon pools and soil respiration in the southern Appalachian Mountains, For. Sci. 51 (2005) 372-383.

[39] M. Liu, Z. Yu, Y. Liu, N.T. Konijn, Fertilizer requirements for wheat and maize in China: the QUEFTS approach, Nutr. Cycl. Agroecosyst. 74 (2006) 245-258, http://dx.doi.org/10.1007/s10705-006-9002-5.

[40] A. Desrochers, S.M. Landhäusser, V.J. Lieffers, Coarse and fine root respiration in aspen (Populus tremuloides), Tree Physiol. 22 (2002) 725-732.

[41] M.G.R. Cannell, J.H.M. Thornley, Modelling the components of plant respiration: some guiding principles, Ann. Bot. 85 (2000) 45-54.

[42] G. Han, Y. Luo, D. Li, J. Xia, Q. Xing, J. Yu, Ecosystem photosynthesis regulates soil respiration on a diurnal scale with a short-term time lag in a coastal wetland, Soil Biol. Biochem. 68 (2014) 85-94, http://dx.doi.org/10.1016/ j.soilbio.2013.09.024. 
[43] J. Tang, L. Misson, A. Gershenson, W. Cheng, A.H. Goldstein, Continuous measurements of soil respiration with and without roots in a ponderosa pine plantation in the Sierra Nevada Mountains, Agric. For. Meteorol 132 (2005) $212-227$

[44] Y. Luo, Soil Respiration and the Environment, Elsevier Academic Press,
Amsterdam ;; Boston, 2006.

[45] E. Tomè, M. Tagliavini, F. Scandellari, Recently fixed carbon allocation in strawberry plants and concurrent inorganic nitrogen uptake through arbuscular mycorrhizal fungi, J. Plant Physiol. 179 (2015) 83-89. http://dx.doi.org/ 10.1016/j.jplph.2015.02.008 